\title{
Implementasi Pendidikan Karakter di Madrasah Ibtidaiyah
}

\author{
Rahmat Rifai Lubis \\ Sekolah Tinggi Agama Islam Sumatera-Medan \\ E-Mail: pailubis8@gmail.com \\ Miftahul Husni Nasution \\ Universitas Islam Negeri Raden Fatah Palembang \\ E-Mail: Miftahulhusninst@yahoo.co.id.
}

\begin{abstract}
Since 2010, Through the Ministry of National Education, The government proclaimed the implementation of character education for all levels of education, from elementary school to university level. This program has been proclaimed with many reasons. Because, along this time the educational world is considered unsuccesfull in order to create nation's generation that has character and dignity. Due to the demoralization and moral decadence of the nation that has collapsed, it is one of the causes of the emergence of character education. Yahya Kan explains that character education is learning process by familiarizing children to think and behave and to help individual to live and cooperating as a family, society and nation, and also to help others to make responsible decisions. There are several models of implementation of character education in Madrasah Ibtidaiyah, 1) Model as an individual subject (monolithic), 2). Integrated model in all field of study, 3).Model outside of teaching, 4).Combined model. And then, the implementation of character education can be done through the implementation of integrated character education: 1). Integration in self-development programs, there are: integrated in routine school activities, integrated in spontaneous activities, integrated in exemplary, and integrated in conditioning, 2). Integration in subjects, 3). Integration in school culture.
\end{abstract}

\begin{abstract}
Abstrak
Sejak tahun 2010, pemerintah melalui Kementerian Pendidikan Nasional mencanangkan penerapan pendidikan karakter bagi semua tingkat pendidikan, baik sekolah dasar hingga perguruan tinggi.Program ini dicanangkan bukan tanpa alasan. Sebab, selama ini dunia pendidikan dinilai kurang berhasil dalam mengantarkan generasi bangsa menjadi pribadi-pribadi berkarakter dan bermartabat. Disebabkan demoralisasi dan dekandensi moral bangsa yang sudah terpuruk salah satu penyebab munculnya pendidikan karakter. Yahya Kan menjelaskan bahwa pendidikan karakter adalah proses pembelajaran dengan membiasakan anak untuk berpikir dan berprilaku dan membantu individu untuk hidup dan bekerja sama sebagai keluarga, masyarakat an bangsa, serta membantu orang lain utuk membuat keputusan yang dapat dipertanggung jawabkan. Ada beberapa model-model Penerapan Pendidikan Karakter di Madrasah Ibtidaiyah, 1) Model sebagai mata pelajaran tersendiri (monolitik), 2).Model terintegrasi dalam semua bidang studi, 3).Model di luar pengajaran, 4). Model gabungan. Kemudian berkenaan dengan implementasi pendidikan karakter dapat dilakukan melalui implementasi Pendidikan Karakter Terintegrasi, antara lain:1) Pengintegrasian dalam program pengembangan diri antara lain terintegrasi pada kegiatan rutin disekolah, terintegrasi pada kegiatan spontan, terintegrasi pada keteladanan, dan terintegrasi pada pengkondisian. 2). Pengintegrasian Pada Mata Pelajaran. 3). Pengintegrasian Dalam Budaya Sekolah.
\end{abstract}


Kata Kunci: Implementasi, Pendidikan Karakter, Madrasah Ibtidaiyah

\section{A. Pendahuluan}

Sejak tahun 2010, pemerintah melalui Kementerian Pendidikan Nasional mencanangkan penerapan pendidikan karakter bagi semua tingkat pendidikan, baik sekolah dasar hingga perguruan tinggi.Program ini dicanangkan bukan tanpa alasan. Sebab, selama ini dunia pendidikan dinilai kurang berhasil dalam mengantarkan generasi bangsa menjadi pribadi-pribadi berkarakter dan bermartabat. Dan bisa juga dikatakan bahwa selama ini pendidikan gagal dalam aspek karakter, dimana sekolah terlalu terpesona dengan target-target akademis, dan melupakan pendidikan karakter, realitas ini membuat kreativitas, keberanian menghadapi resiko, kemandirian dan kesabaran dalam menghadapi ujian menjadi sangat rendah, yang menyebabkan anak mudah frustasi, menyerah, dan kehilangan semangat juang.

Di sisi lain, penduduk Indonesia yang mayoritas beragama Islam yang sedianya mampu mewujudkan nilai-nilai Islam untuk membangun bangsa yang menjungjung nilai demokrasi, toleransi dan humanisasi masih sering sekali menimbulkan pertanyaaan. Sering kali kita dengar kelompok yang melakukan tindak kekerasan atas nama Islam untuk membungkam kelompok atau organisasi lain. Disamping itu masih banyak umat Islam memahami Islam secara tekstual sehingga mendatangkan sikap ekstrim, yang demikian itu menunjukkan belum memahami Islam secara komprehensif.Sedangkan ditingkat eksternal, pendidikan Islam dewasanya sedang dihadapkan dengan era globasasi yang ditandai denganteknologi informasi yang pada prinsipnya melemahkan daya mental spiritual ummat manusia, sehingga dengan dampak teknologi diatas akan menjadikan manusia jauh dari nilai-nilai keagamaan atau hilangnya karakter keislaman (Said Aqil Siraj, 2007: 8).

Selain itu ada beberapa contoh problematika yang menyangkut tatanan nilai dalam masyarakat yang tak kunjung dapat diselasaikan seperti korupsi, tawuran, antar sekolah, free sex, nepotisme, budaya sogok menyogok, yang semuanya itu sudah menjadi karakter dari bangsa kita. Dari karakter-karakter yang mengakar pada diri bangsa Indonesia tersebut tidak bisa dihindari tanpa melalui pendidikan yang bisa menumbuhkan nilai-nilai karakter bangsa yang terpuji.

Selama ini pendidikan yang diselenggarakan oleh pemerintah masih menafikan karakter, pendidikan kita sibuk menyusun desain pembelajaran dengan meletakkan pilihan a.b, atau c, sebagai evaluasi terakhir tanpa memperhatikan bagaimana penddikan itu dapat berdampak terhadap perubahan prilaku. Kita bangga menyaksikan anak-anak didik begitu terampil dalam mencawab soal cerdas cermat dan begitu cepat dalam memainkan pensil 2bnya diatas isian soal-soal ujian akhir, sembari menutup mata bahwa semakin hari mereka tampil sebagai orang asing orang yang terpecah (cerdas tanpa moral dan karakter)

Pendidikan karakter adalah sebuah pilihan untuk memperbaiki karakter bangsa yang sudah terpuruk, dimana dekadensi moral sudah sangat memprihatinkan. Maka 
akan sangat berbahaya jika hal ini terus dibiarkan, dan juga akan mengancam dan memperburuk citra karakter bangsa Indonesia dimata negera lain yang masih rentan dianggap bangsa yang berbudaya, ramah, sopan, dan mempunyai nilai sosial yang tinggi.

Dalam UU No 20 Tahun 2003 Tentang Sistem Pendidikan Nasional pada pasal 3 yangmenyebutkan bahwa pendidikan nasional berfungsi mengembangkan kemampuan dan untuk membentuk karakter serta peradaban bangsa yang bermartabat dalam rangka mecerdasakan kehidupan bangsa. Pendidikan nasional bertujuan untuk mengembangkan potensi peserta didik agar menjadi manusia yang beriman dan bertaqwa kepada Tuhan Yang Maha Esa, berakhlak mulia, sehat, berilmu, cakap, kreatif, mandiri, dan menjadi warga Negara yang demokratis serta bertanggung jawab(Masnur Muslich, 2011: 8384).Dari berbagai dasar diatas dapat di pahami bahwa pendidikan karakter adalah tujuan pendidikan nasional, maka tidak ada keraguan lagi bahwa pendidikan karakter menjadi rogram penting untuk memperbaiki karakter bangsa

Terkait implementasi pendidikan karakter, beberapasekolah swasta unggul yang mandiri pada tahun 2010 yang lalu, mulai dari TK, SD, SMP, SMA, juga SMK memang sudah melakukan atau melaksanakan pendidikan karakter, jauh sebelum pemerintah berkeinginan melaksanakan pendidikan karakter bagi sekolah-sekolah di Indonesia. Pada tahun 2011 pemerintah sudah menerapkan pendidikan karakter hampir di seluruh Indonesia yakni dengan mengintegrasikan pendidikan karakter kedalam mata pelajaran, program pengembangan diri, dan budaya sekolah.

Terkait pendidikan karakter, Pemerintah sudah membuat pedoman dalam penerapan pendidikan karakter yang dikembangkan dari pendekatan integrasi, sehingga pendidikan tidak hanya diintegrasikan pada setiap bidang studi/mata pelajaran namun dikembangkan dan diintegrasikan dalam program pengembangan diri, dan budaya sekolah. Akan tetapi program ini pada kenyataannya tidak berjalan mulus seperti yang diharapkan.Masih banyak sekolah yang hanya mengintegrasikan pada mata pelajaran saja, namun itupun hanya sekedar tertera dalam RPP dan silabus. Akan tetapi dalam proses pembelajaran di kelas masih banyak guru yang tidak menerapkannya dan mengaplikasikannya. Terkait pengintegrasiannya terhadap program pengembangan diri dan budaya sekolah juga tidak jauh berbeda, masih banyak pihak sekolah belum siap dalam mengimplementasikan pendidikan karakter dengan berbagai faktor-faktor yang menghambat berjalannya proses pengintegrasian pendidikan karakter tersebut, salah satunya adalah fasilitas yang tidak memadai, kesadaran diri para guru-guru dan juga pihak sekolah, kurang sosialisasi bagaimana implementasi pendidikan karakter yang ideal dan masih banyak lagi.

\section{B. Pembahasan}

\section{Pengertian Pendidikan karakter}

Terkait dengan pendidikan karakter banyak para ahli memberikan defenisi, Yahya Kan menjelaskan bahwa pendidikan karakter adalah proses pembelajaran dengan 
membiasakan anak untuk berpikir dan berprilaku dan membantu individu untuk hidup dan bekerja sama sebagai keluarga, masyarakat an bangsa, serta membantu orang lain utuk membuat keputusan yang dapat dipertanggung jawabkan (D. Yahya Kan, 2010: 1-2).

Pendidikan karakter adalah sebuah system yang menanamkan nilai-nilai karakter pada peserta didik yang mengandung komponen-kompenen pengetahuan, kesadaran individu, tekad, serta adanya kemauan dan tindakan untuk melaksanakan nilai-nilai baik terhadap Tuhan Yang Maha Esa, diri sendiri, sesama manusia, lingkungan dan juga bangsa sehingga akan terwujud insan kamil (Nurla Isna Ainullah, 2011: 18).

Winton dalam Muchlas samani dan Hariyanto menjelaskan bahwa pendidikan karakter adalah upaya sadar dan sungguh-sungguh dari seorang guru untuk mengajarakan nilai-nilai kepada siswanya. Kemudian Muchlas samani dan Hariyanto memberikan defenisi sederhana tentang pendidikan karakter mereka berpendapat bahwa pendidikan karakter adalah hal positif apa saja yang di lakukan oleh guru dan berpengaruh kepada karakter siswa yang diajarnya (Muchlas Samani \& Hariyanto).

Ratna Megawangi dalam Darma Kesuma dkk, menjelaskan bahwa pendidikan karakter adalah sebuah usaha untuk mendidik anak-anak agar dapat mengambil keputusan dengan bijak dan mempraktikkannya dalam kehidupan sehari-hari, sehingga mereka dapat memberikan kontribusi yang positif terhadap lingkungannya (Darma Kesuma dkk, 2011: 5).

Menurut T. Ramli dalam Muhammad Walid menjelaskan bahwa pendidikan karakter memiliki esensi dan makna yang sama dengan pendidikan moral dan pendidikan akhlak. Tujuannya adalah membentuk pribadi anak, supaya menjadi manusia yang baik, warga masyarakat, dan warga Negara yang baik.Untuk mencapai tujuan tersebut, sangat dipengeruhi oleh nilai-nilai sosial yang ada dalam masyarakat dan bangsanya. Maka pendidikan karakter dalam konteks pendidikan di Indonesia adalah pendidikan nilai, yakni pendidikan nilai luhuryang bersumber dari budaya bangsa Indonesia sendiri, dalam rangka membina kepribadian genarasi muda (Muhammad Walid, 2011: 120).

Pendidikan karakter bukanlah suatu proses pengetahuan peserta didik untuk menghafal materi soal ujian, dan teknik-teknik mejawabnya. Pendidikan karakter adalah suatu proses pembiasaan, pembiasaan untuk berbuat baik, pembiasaan untuk berkata dan berlaku jujur, ksatria, malu berbuat curang, malu bersikap malas, tidak suka dengan lingkungan yang kotor. Karakter itu tidak terbentuk semudah membalikkan telapak tangan (instan), tapi butuh ketekunan dan latihan yang serius dan proporsional agar menjadi bentuk dan kekuatan yang ideal (Adian Husaini, 2010: 25).

Dari beberapa defenisi di atas dapat disimpulakan bahwa pendidikan karakter adalah penanaman nilai-nilai, akhlak, moral yang menjadi tanggung jawab semua staf sekolah tanpa terkecuali, baik dalam proses pembelajaran, budaya sekolah dan juga 
manajemen sekolah, sehingga dengan itu akan tercipta efektifitas dalam mencapai tujuan pendidikan yakni generasi bangsa yang tangguh dan mempunyai karakter yang baik (insan kamil).

\section{Model-model Penerapan Pendidikan Karakter}

Keberhasilan dalam menyelenggarakan dan menanamkan nilai-nilai kehidupan melalui pendidikan karakter dapat pula dipengaruhi oleh cara ataupun pendekatan yang dipergunakan alam menyampaikannya. Menurut Suparno dkk, ada empat model pendekatan penyampaian pendidikan karakter, antara lain:

a. Model sebagai mata pelajaran tersendiri (monolitik)

Dalam model pendekatan ini, pendidikan karakter dianggap sebagai mata pelajaran tersendiri. Oleh karena itu, pendidikan karakter mempunyai kedudukan yang sama dan di perlakukan sama seperti pelajaran atau bidang studi lain. Dalam hal ini, guru bidang studi pendidikan karakter harus mempersiapkan dan mengembangkan kurikulum, mengembangkan silabus, membuat rancangan proses pembelajaran (RPP), metodologi pembelajaran, dan evaluasi pembelajaran. Konsekuensinya pendidikan karakter harus dirancangkan dalam jadwal pelajaran yang terstruktur (Suparno, dkk, 2002: 42).

Kelebihan pendekatan ini antara lain adalah materi yang di sampakan akan lebih terarah dan terencana matang dan terfokus, materi yang disampaikan lebih terukur. Sedangkan kelemahan pendekatan ini adalah sangat tergantung pada tuntutan kurikulum, kemudian penenaman nilai tersebut seolah-olah menjadi tanggung jawab seorang guru semata, demikian pula dampak yang muncul pendidikan karakter hanya menyentuh aspek kognitif, tidak menyentuh internalisasi nilai tersebut (Suparno, dkk, 2002: 42).

Pendekatan model ini adalah pendekatan model lama, dimana nilai-nilai karakter dimuat dalam satu mata pelajaran dan kemuadian diajarkan dan di transfer melalui pembelajaran di kelas, banyak para pakar menilai bahwa model ini sudah tidak layak dan tidak mampu untuk menghantarkan siswa-siswi menjadi pribadi yang berkarakter. Karna perkembangan jaman dan juga kondisi yang mengakibatkan perlunya model-model yang lebih membiasakan internalisasi nilai-nilai dalam kehidupan.

b. Model terintegrasi dalam semua bidang studi

Pendekatan yang kedua dalam menerapakan pendididikan karakter adalah disampaikan secara terintegrasi dalam setiap bidang pelajaran, dan oleh karena itu penerapan pendidikan karakter menjadi tanggung jawab semua guru.Dalam konteks ini guru dapat memilih pendidikan karakter yang sesuai dengan tema dan pokok bahasan bidang studi. Melalui model integrasi ini maka setiap guru adalah pengajar pendidikan karakter tanpa terkecuali(Achmad Husein dkk, 2010: 31). 
Keunggulan model terintegrasi pada setiap bidang studi antara lain setiap guru ikut bertanggung jawab akan penanaman nilai-nilai hidup kepada setiap siswa, disamping itu pemahaman nilai-nilai pendidikan karakter cendrung tidak bersifat informative-kognitif, melainkan bersifat aplikatif sesuai dengan konteks pada setiap bidang studi. Dampaknya positifnya terhadap siswa adalah akan lebih terbiasa dengan nilai-nilai yang sudah diterapkan dalam berbagai seting(Achmad Husein dkk, 2010: 31).

Dan adapun sisi kelemahannya adalah pemahaman dan persepsi tentang nilai yang akan di tanamkan harus jelas dan sama pada semua guru. Namun, mejamin kesamaan pada setiap guru adalah hal yang tidak akan mudah, hal ini mengingat latar belakang dari stiap guru yang berbeda-beda. Di samping itu, jika terjadi perbedaan penafsiran nilai-nilai di antara guru akan mengakibatkan siswa bingung(Achmad Husein dkk, 2010: 31-32).

\section{c. Model di luar pengajaran}

Penanaman nilai-nilai karakter dapat juga di tanamkan dan di terapkan di luar kegiatan pembelajaran formal.Pendekatan ini lebih mengutakan pengolahan dan penanaman nilai melalui suatu kegiatan untuk dibahas dan kemudian dibahas nilai-nilai hidupnya. Model kegiatan demikian dapat dilaksanakan oleh guru sekolah yang diberi tugas tersebut atau dipercayakan kepada lembaga lain untuk melaksanakannya. Kelebihan pendekatan ini adalah siswa dapat endapatkan pengalaman secara langsung dan kongkrit. Kelemahannya adalah tidak ada dalam struktur tetap dalam kerangka pendidikan dan pengajaran di sekolah, sehingga akan membutuhkan waktu yang lebih lama dan biaya yang lebih banyak(Achmad Husein dkk, 2010: 32).

\section{d. Model gabungan}

Pendekatan model gabungan adalah menggabungkan antara model integrasi dan model luar pengajaran secara bersama. Model ini dapat dilaksanakan dalam kerja sama dengan tim baik oleh guru maupun kerja sama dengan pihak luar sekolah. Kelebihan model ini adalah semua guru terlibat, disamping itu guru dapat belajar dari pihak luar untuk mengembangkan diri dan siswa.Siswa menerima informasi tentang nilai-nilai sekaligus di perkuat dengan pengalaman melalui kegiatan-kegiatan yang terencana dengan baik. Mengingat pendidikan karakter merupakan salah satu fungsi pendidikan Nasional, maka sepatutnya pendidikan karakter ada pada setiap materi pelajaran(Achmad Husein dkk, 2010: 32).

Dari beberapa model di atas adalah model implementasi pendidikan karakter yang mempunyai kelebihan dan kekurangannya masing-masing, namun beberapa model diatas juga sudah mulai dikembangkan oleh para pakar dan ahli karna di anggap sudah tidak mampu menghantarkan peserta didik menjadi pribadi-pribadi yang bermartabat dan berkarakter baik. Namun bukan berarti model lama dilupakan begitu saja, akan tetapi tetap digunakan namun dikembangkan sehingga 
akan mempermudah untuk tercapainya tujuan pendidikan yakni menjadikan peserta didik menjadi insane-insan yang beriman dan bertaqwa kepada tuhan yang nmaha esa, berakhlak mulia, sehat, berilmu, cakap, kreatif, mandiri, bertanggung jawab dan menjadi warga Negara yang demokratis.

\section{Implementasi Pendidikan Karakter Di Sekolah/Madrasah}

Pada mellenium kedua ini, Indonesia memerlukan sumberdaya manusia dalam jumlah dan mutu yang memadai sebagai pendukung utama dalam pembangunan.Untuk memenuhi sumberdaya manusia tersebut, pendidikan memiliki peran yang sangat penting. Sebagaiman yang telah di ungkapkan oleh Muhibbin Syah dalam bukunya psikologi belajar, bahwa proses perkembangan moral (karakter) anak sangat di pengaruhi proses belajar. Perkembangan karakter anak berkaitan erat dengan kegiatan belajar, kualitas hasil perkembangan moral (karakter) siswa bergantung pada kualitas belajar anak baik di lingkungan sekolah, keluarga maupun lingkungan yang lebih luas(Muhibbin Syah,2009: 37).

Hal ini sesuai dengan UU No 20 Tahun 2003 Tentang Sistem Pendidikan Nasional pada pasal 3 yangmenyebutkan bahwa pendidikan nasional berfungsi mengembangkan kemampuan dan untuk membentuk karakter serta peradaban bangsa yang bermartabat dalam rangka mecerdasakan kehidupan bangsa. Pendidkan nasional bertujuan untuk mengembangkan potensi peserta didik agar menjadi manusia yang beriman dan bertaqwa kepada Tuhan Yang Maha Esa, berakhlak mulia, sehat, berilmu, cakap, kreatif, mandiri, dan menjadi warga Negara yang demokratis serta bertanggung jawab (Masnur Muslich, 2011: 83-84).

Karakter merupakan nilai-nilai perilaku manusia yang berhubungan dengan Tuhan Yang Maha Esa, diri sendiri, sesama manusia, lingkungan, dan kebangsaan dalam pikiran, sikap, perasaan, perkataan, dan perbuatan berdasarkan norma-norma agama, hukum, tata kerama, budaya dan adat istiadat. Pendidikan karakter adalah suatu system penanaman nilai-nilai karakter kepada warga sekolah yang meliputi komponen pengetahuan, kesadaran atau kemauan, dan tindakan untuk melaksanakan nilai-nilai tersebut, baik terhadap Tuhan Yang Maha Esa, diri sendiri, sesama, lingkungan, maupun kebangsaan sehingga menjadi manusia insan kamil. Dalam pendidikan karakter di sekolah, semua komponen (stakeholder) harus dilibatkan, termasuk komponenkomponen itu sendiri, yaitu isi kurikulum, proses pembelajaran dan penilaian, kualitas hubungan, penanganan atau pengelolaan mata pelajaran, pengelolaan sekolah, pelaksanaan aktivitas atau kegiatan kokurikuler, pemberdayaan sarana prasarana, pembiayaaan dan ethos kerja seluruh warga dan lingkungan ( Masnur Muslich, 2011: 84$85)$.

Untuk mengetahui keberhasilan implementasi pendidikan karakter di Sekolah dan Madrasah, maka ada beberapa indidkator dari 18 nilai yang di tetapkan oleh pemerintah dan juga akan menjadi tolok ukur bagi keberhasilan implemantasi 
pendidikan karakater. Berikut beberapa indikatornya yang akan di sajikan dalam bentuk tabel sebagai berikut: (Agus Wibowo, 2012: 85)

Tabel: 2.1

Indikator Keberhasilan Pendidikan Karakter

\begin{tabular}{|c|c|c|}
\hline No & Nilai & Indikator \\
\hline 1 & Religius & $\begin{array}{l}\text { a. Mengucapkan salam } \\
\text { b. Berdo'a sebelum dan sesudah belajar } \\
\text { c. Melaksanakan ibadah keagamaan } \\
\text { d. Merayakan hari raya besar keagamaan }\end{array}$ \\
\hline 2 & Jujur & $\begin{array}{l}\text { a. Membuat dan mengerjakan tugas dengan benar } \\
\text { b. Tidak menyontek dan memberi contekan } \\
\text { c. Membanngun koperasi dan kantin kejujuran } \\
\text { d. Melaporkan kegiatan sekolah secara trasparan } \\
\text { e. Melakukan system perekrutan siswa secara benar } \\
\text { dan adil } \\
\text { f. Melakukan system peneliaian yang akuntabel dan } \\
\text { tidak melakukan dan manipulasi }\end{array}$ \\
\hline 3 & Toleransi & $\begin{array}{l}\text { a. Memberlakukan orang lain dengancara yang sama } \\
\text { dan tidak membeda-bedakan agama, suku, ras, dan } \\
\text { golongan } \\
\text { b. Menghargai perbedaan yang ada tanpa melecehkan } \\
\text { kelompok yang lain }\end{array}$ \\
\hline 4 & Disiplin & $\begin{array}{l}\text { a. Guru dan siswa hadir tepat waktu } \\
\text { b. Menegakkan prinsip dengan memberikan } \\
\text { punishment bagi yang melanggar dan reward bagi } \\
\text { yang berprestasi } \\
\text { c. Menjalankan tata tertib sekolah. }\end{array}$ \\
\hline 5 & Kerja keras & $\begin{array}{l}\text { a. Pengelolaan pembelajaran yang menantang } \\
\text { b. Mendorong semua warga sekolah untuk berprestasi } \\
\text { c. Berkompetisi secara fair } \\
\text { d. memberikan penghargaan kepada siswa berprestasi }\end{array}$ \\
\hline 6 & kreatif & $\begin{array}{l}\text { a. Menciptakan ide-ide baru di sekolah } \\
\text { b. Menghargai setiap karya yang unik dan berbeda } \\
\text { c. Membangun suasana belajar yang mendorong } \\
\text { munculnya kreatifitas siswa }\end{array}$ \\
\hline 7 & mandiri & $\begin{array}{l}\text { a. Melatih siswa agar mampu bekerja sendiri secara } \\
\text { mandiri } \\
\text { b. Membangun kemandirian siswa melalui tugas-tugas } \\
\text { yang bersifat individu }\end{array}$ \\
\hline
\end{tabular}




\begin{tabular}{|c|c|c|}
\hline 8 & demokratis & $\begin{array}{l}\text { a. Tidak memaksakan kehendak kepada orang lain } \\
\text { b. Sistem pemelihan ketua kelas dan pengurus kelas } \\
\text { secara demokratis } \\
\text { c. Mendasarkan setiap keputusan pada musyawarah } \\
\text { mufakat }\end{array}$ \\
\hline 9 & Rasa ingin tahu & $\begin{array}{l}\text { a. Sistem pembelajaran diarahkan untuk } \\
\text { mengeksplorasi keingintahuan siswa } \\
\text { b. Sekolah memberikan fasilitas, baik melalui media } \\
\text { cetak maupun elektronik, agar siswa dapat mencari } \\
\text { informasi yang baru }\end{array}$ \\
\hline 10 & Semangat kebangsaan & $\begin{array}{l}\text { a. Memperingati hari besar } \\
\text { b. Meneladani para pahlawan } \\
\text { c. Berkunjung kepada tempat-tempat bersejarah } \\
\text { d. Melaksanakan upacara rutin sekolah } \\
\text { e. Mengikut sertakan kepada kegiatan-kegiatan } \\
\text { kebangsaan } \\
\text { f. Memajang tokoh-tokoh bangsa }\end{array}$ \\
\hline 11 & Cinta tanah air & $\begin{array}{l}\text { a. Menanamkan nasionalisme dan rasa persatuan dan } \\
\text { kesatuan bangsa } \\
\text { b. Menggunakan bahasa Indonesia dengan baik dan } \\
\text { benar } \\
\text { c. Memajang bendera Indonesia, pancasila, dengan } \\
\text { baik dan benar } \\
\text { d. Bangga dengan karya bangsa } \\
\text { e. Melestarikan seni dan budaya bangsa }\end{array}$ \\
\hline 12 & Menghargai prestasi & $\begin{array}{l}\text { a. Mengabadikan dan memajang hasil karya siswa dan } \\
\text { sekolah } \\
\text { b. Memberikan reward stiap warga sekolah yang } \\
\text { berprestasi } \\
\text { c. Melatih dan membina generasi penerus untuk } \\
\text { mencontoh hasil atau prestasi generasi sebelumnya. }\end{array}$ \\
\hline 13 & Besahabat/Komunikatif & $\begin{array}{l}\text { a. Saling menghargai dan menghormati } \\
\text { b. Guru menyayangi siswa dan siswa menghormati } \\
\text { guru } \\
\text { c. Tidak menjaga jarak } \\
\text { d. Tidak membeda-bedakan dalam berkomunikasi }\end{array}$ \\
\hline 14 & Cinta damai & $\begin{array}{l}\text { e. Menciptakan suasana kelas yang tentram } \\
\text { f. Tidak menoleransi segala bentuk kekerasan } \\
\text { g. Mendorong terciptanya harmonisasi kelas dan } \\
\text { sekolah }\end{array}$ \\
\hline 15 & Gemar membaca & $\begin{array}{l}\text { a. Mendorong dan memfasilitasi siswa untuk gemar } \\
\text { membaca }\end{array}$ \\
\hline
\end{tabular}




\begin{tabular}{|c|c|c|}
\hline & & $\begin{array}{l}\text { b. Setiap pembelajaran didukung dengan sumber } \\
\text { bacaan atau referensi } \\
\text { c. Adanya ruang baca, baik di perpustakaan maupun } \\
\text { raung khusus tertentu } \\
\text { d. Menyediakan buku-buku sesuai tahap perkembangan } \\
\text { siswa } \\
\text { e. Menyediakan buku-buku yang dapat menarik minat } \\
\text { baca siswa }\end{array}$ \\
\hline 16 & Peduli lingkungan & $\begin{array}{l}\text { a. Menjaga lingkungan kelas dan sekolah } \\
\text { b. Memelihara tumbuh-tumbuhan dengan baik tanpa } \\
\text { menginjak atau merusaknya } \\
\text { c. Mendukung program go green (penghijauan) di } \\
\text { lingkungan sekolah } \\
\text { d. Tersedianya tempat untuk membuang sampah } \\
\text { organik dan nonorganic } \\
\text { e. Menyediakan kamar mandi, air bersih, dan tempat } \\
\text { cuci tangan. }\end{array}$ \\
\hline 17 & Peduli sosial & $\begin{array}{l}\text { a. Sekolah memberikan bantuan kepada siswa yang } \\
\text { kurang mampu } \\
\text { b. Melakukan kegiatan bakti sosial } \\
\text { c. Melakukan kunjungan di daerah atau kawasan } \\
\text { marginal } \\
\text { d. Memberikan bantuan kepada lingkungan masyarakat } \\
\text { yang kurang mampu } \\
\text { e. Menyediakan kotak amal tau sumbangan }\end{array}$ \\
\hline 18 & Tanggung jawab & $\begin{array}{l}\text { a. Mengerjakan tugas dan pekerjaan rumah dengan } \\
\text { baik } \\
\text { b. Bertanggung jawab terhadap setiap perbuatan } \\
\text { c. Melakukan piket sesuai dengan jadwal yang telah } \\
\text { ditetapkan } \\
\text { d. Mengerjakan tugas kelompok secara bersama-sama. }\end{array}$ \\
\hline
\end{tabular}

Dari 18 nilai pendidikan karakter dan juga dari beberapa indikator dari masingmasing nilai pendidikan karakter di atas akan menjadi parameter pelaksanaan pendidikan karakter di Sekolah dan Madrasah. Jika indicator tersebut telah terpenuhi dan sudah diinternalisasikan oleh siswa di sekolah dan juga dalam kehidupannya maka pendidikan karakter sudah terlaksana.

Namun untuk lebih jelas dan terperinci bagaimana implementasi pendidikan karakter di Sekolah dan Madrasah maka akan di jelaskan sebagai berikut: 


\section{a. Implementasi Pendidikan Karakter Yang Diintegrasikan Pada Pengembangan Diri}

Adapun Implementasi pendidikan karakter yang diintegrasikan pada pengembangan diri di Sekolah dan Madrasah melalui empat hal sebagai berikut:

1) Kegiatan Rutin Sekolah

Dimana bentuk implementasinya akan dijelaskan dalam bentuk tabel sebagai berikut:

Tabel: 2.2

Implementasi Pendidikan Karakter Di Sekolah/Madrasah Dengan Kegiatan Rutin

Sekolah

\begin{tabular}{|c|c|}
\hline $\begin{array}{l}\text { Nilai-Nilai } \\
\text { Pendidikan } \\
\text { Karakter }\end{array}$ & Bentuk Kegiatan atau Pelaksanaan \\
\hline Religius & $\begin{array}{l}\text { 1) Berdo'a sebelum dan sesudah pelajaran } \\
\text { 2) Setiap pergantian jam pelajaran, siswa memberi salam } \\
\text { kepada guru } \\
\text { 3) Melakukan sholat Zuhur berjama'ah sesuai waktu yang } \\
\text { ditentukan } \\
\text { 4) Mengucapkan salam ketika bertemu guru, orang tua, } \\
\text { karyawan, dan sesama peserta didik } \\
\text { 5) Mengetuk pintu dan mengucap salam sebelum masuk } \\
\text { keruangan orang lain } \\
\text { 6) Meminta izin memakai barang orang lain }\end{array}$ \\
\hline Kedisiplinan & $\begin{array}{l}\text { 1) Membuat catatan kehadiran pendidik dan peserta didik } \\
\text { 2) Seluruh warga sekolah melakukan senam kesegaran jasmani } \\
\text { 3) Seluruh siswa dan sudah berada di sekolah dengan rentang } \\
\text { waktu yang ditentukan dan diberikan toleransi } 15 \text { menit, dan } \\
\text { juga siswa pulang dengan jadwal yang ditetapkan. Maka } \\
\text { siswa yang melanggar akan di beri sanksi pihak sekolah } \\
\text { 4) Begitu juga guru dan pegawai tata usaha harus datang tepat } \\
\text { waktu dan bagi guru yang tidak tepat waktu akan di beri } \\
\text { sanksi pihak sekolah dan pulangnya sesuai dengan jadwal } \\
\text { 5) Bila berhalangan hadir baik guru, tata usaha, siswa harus ada } \\
\text { pemberitahuan ke sekolah } \\
\text { 6) Mengecek kerapian dan kebersihan pakaian, yang di lakukan } \\
\text { oleh seluruh guru setiap harinya, dan bagi siswa yang tidak } \\
\text { berpakaian rapi di minta merapikannya dan di beritahu cara } \\
\text { merapikannya } \\
\text { 7) Mengecek kerapian rambut dengan ukuran panjang yang } \\
\text { telah di tentukan, jika melanggar di beri peringatan atau } \\
\text { sanksi oleh pihak sekolah }\end{array}$ \\
\hline
\end{tabular}




\begin{tabular}{|c|c|}
\hline & $\begin{array}{l}\text { 8) Guru dan pegawai berpakaian rapi } \\
\text { 9) Mengambil sampah yang berserakan } \\
\text { 10) Meminjam dan mengembalikan sendiri buku perpustakaan } \\
\text { pada guru perpustakaan }\end{array}$ \\
\hline Peduli lingkungan & $\begin{array}{l}\text { 1) Membiasakan anak untuk membuang sampah pada } \\
\text { tempatnya } \\
\text { 2) Setiap jam terakhir siswa melakukan kebersihan dan } \\
\text { memungut sampah disekitar kelasnya didamping guru yang } \\
\text { mengajar pada jam terakhir } \\
\text { 3) Membuag sampah kelas ke TPS } \\
\text { 4) Setiap hari jum'at di tetapkan sebagai jum'at bersih dengan } \\
\text { waktu yang di tentukan } \\
\text { 5) Menyiapkan petugas kebersihan untuk membersihkan } \\
\text { sampah yang tidak terjangkau siswa } \\
\text { 6) Membuat piket kelompok untuk kebersihan ruangan masing- } \\
\text { masing setelah pulang sekolah } \\
\text { 7) Melarang siswa untuk mencoret tembok, bangku, meja atau } \\
\text { fasilitas sekolah, bagi yang kedapatan di beri sanksi oleh } \\
\text { pihak sekolah }\end{array}$ \\
\hline Peduli sosial & $\begin{array}{l}\text { 1) Mengunjungi panti jompo dengan memberikan sumbangan } \\
\text { 2) Mengunjungi panti asuhan juga dengan sumbangan } \\
\text { 3) Mengmpulkan sumbangan pada momen tertentu, misalnya } \\
\text { gempa bumi, kebakaran, banjir, dan lain-lain } \\
\text { 4) Mengunjungi teman yag sakit }\end{array}$ \\
\hline kejujuran & $\begin{array}{l}\text { 1) Menyediakan tempat temuan barang hilang } \\
\text { 2) Larangan memngambil barang yang bukan milik kita } \\
\text { 3) Larangan mencontek dalam ujian }\end{array}$ \\
\hline Cinta tanah air & $\begin{array}{l}\text { 1) Menggunkan bahasa Indonesia yang baik dan benar } \\
\text { 2) Menyanyikan lagu kebangsaan setiap upacara bendera dan } \\
\text { peringatan hari besar nasional } \\
\text { 3) Memajang foto pahlawan nasional } \\
\text { 4) Menggunakan produk buatan negeri }\end{array}$ \\
\hline
\end{tabular}

Tabel di atas, adalah menunjukkan bagaimana implementasi pendidikan karakter di sekolah/madrasah dengan kegiatan rutin, dimana kegiatan rutin tersebut selalu disisipkan atau dipadukan karakter-karakter yang sesuai, sehingga peserta didik akan terbiasa dengan karakter tersebut (Agus Wibowo, 2012: 85).

\section{2) Kegiatan Spontan}

Kegiatan spontan adalah kegiatan yang datangya secara tiba-tiba tanpa ada perencanaan terlebih dahulu, seperti respon guru terhadap tingkah laku siswa yang salah, selain itu kegiatan-kegiatan sosial yang datang secara tiba- 
tiba seperti bencana alam.Dimana bentuk implementasinya akan dijelaskan dalam bentuk tabel sebagai berikut:

Tabel: 2.3

Implementasi Pendidikan Karakter di Sekolah/Madrasah dengan Kegiatan Spontan

\begin{tabular}{|c|c|}
\hline $\begin{array}{l}\text { Nilai-Nilai } \\
\text { Pendidikan Karakter }\end{array}$ & Bentuk Kegiatan atau Pelaksanaan \\
\hline Religius & $\begin{array}{l}\text { 1) Memperingatkan siswa yang tidak melaksanakan ibadah } \\
\text { 2) Memperingatkan siswa yang tidak mengucapkan salam } \\
\text { 3) Meminta maaf jika melakukan salah } \\
\text { 4) Memperingatkan siswa yang tidak berdo'a sebelum dan } \\
\text { sesudah belajar }\end{array}$ \\
\hline Kedisiplinan & $\begin{array}{l}\text { 1) Memperingatkan siswa yang terlambat, bila masih tetap } \\
\text { terlambat di berikan sanksi yang layak } \\
\text { 2) Bagi guru yang terlambat diberikan teguran dan sanksi } \\
\text { (sesuai dengan peraturan disiplin Pegawai Negeri Sipil) } \\
\text { 3) Melerai pertengkaran dan memperingatinya }\end{array}$ \\
\hline Peduli lingkungan & $\begin{array}{l}\text { 1) Menyuruh siswa yang memungut sampah yang dibuang } \\
\text { sembarangan } \\
\text { 2) Memberikan sanksi kepada siswa yang membuang } \\
\text { sampah sembarangan }\end{array}$ \\
\hline Peduli sosial & $\begin{array}{l}\text { 1) Mengunjungi teman yang sakit } \\
\text { 2) Melayat apabila orang/wali murid yang meninggal } \\
\text { 3) Mengumpulkan sumbangan untuk bencana alam } \\
\text { 4) Membentuk ketua pengumpulan dalam setiap kelas }\end{array}$ \\
\hline kejujuran & $\begin{array}{l}\text { 1) Memperingatkan siswa yang mencontek saat ujian } \\
\text { 2) Memperingatkan siswa yang mencontoh PR temannya }\end{array}$ \\
\hline
\end{tabular}

Terkait tabel di atas adalah menjelaskan bagaimana kegiatan spontan dapat dijadikan wadah untuk menjadikan peserta didik untuk terbiasa melakoni/karakter-karakter yang telah di tetapkan oleh pemerintah (Agus Wibowo, 2012: 88).

3) Keteladanan

Keteladan adalah prilaku dan sikap guru dan tenaga kependidikan yang lain dalam memberikan contoh terhadap tindakan-tindakan yang baik, sehingga diharapkan menjadi panutan bagi peserta didik untuk mencotohnya. Berikut implementasinya di Sekolah/Madrasah yang di jelaskan dengan bentuk tabel: 
Tabel: 2.4

Implementasi Pendidikan Karakter di Sekolah/Madrasah dengan Keteladanan

\begin{tabular}{|c|c|}
\hline $\begin{array}{l}\text { Nilai-Nilai } \\
\text { Pendidikan } \\
\text { Karakter }\end{array}$ & Bentuk Kegiatan atau Pelaksanaan \\
\hline Religius & $\begin{array}{l}\text { 1) Pendidik berdo'a bersama dengan siswa sebelum dan } \\
\text { sesudah jam pelajaran } \\
\text { 2) Pendidik dan tenaga kependidikan melakukan sholat } \\
\text { berjamaah sesuai jadwal yang sudah di tentukan } \\
\text { 3) Guru menjadi model yang baik dalam berdo'a, maka ketika } \\
\text { berdo'a guru harus memberikan contoh dengan berdo'a } \\
\text { dengan khusu' dan dalam bahasa Indonesia sehingga } \\
\text { dimengerti oleh anak }\end{array}$ \\
\hline Kedisiplinan & $\begin{array}{l}\text { 1) Guru harus berda di sekolah tepat waktu yang di tentukan } \\
\text { dan menyambut siswa } \\
\text { 2) Pegawai tata usaha harus tepat waktu dan pulang dengan } \\
\text { waktu yang ditentukan } \\
\text { 3) Mengambil sampah yang berserakan } \\
\text { 4) Berbicara sopan } \\
\text { 5) Mengucapkan terima kasih } \\
\text { 6) Meminta maaf } \\
\text { 7) Menghargai pendapat orang lain }\end{array}$ \\
\hline Peduli lingkungan & $\begin{array}{l}\text { 1) Pendidik dan tenaga kependidikan membuang samapah pada } \\
\text { tempatnya } \\
\text { 2) Pendidik dan tenaga kependidikan bekerja bakti } \\
\text { membersihkan sekolah bersama peserta didik } \\
\text { 3) Pendidik dan tenaga kependidikan mengambil sampah yang } \\
\text { berserakan }\end{array}$ \\
\hline Peduli sosial & $\begin{array}{l}\text { Pendidik dan tenaga kependidikan mengumpulkan sumbangan } \\
\text { setiap ada musibah baik ia bencana alam atau kegiatan sosial }\end{array}$ \\
\hline kejujuran & $\begin{array}{l}\text { 1) Pendidik memberikan penilaian secara objektif } \\
\text { 2) Pendidik menepati janji pada peserta didik }\end{array}$ \\
\hline Cinta tanah air & $\begin{array}{l}\text { Pendidik dan tenaga kependidikan melakukan upacara dan } \\
\text { peringatan hari besar bersama peserta didik }\end{array}$ \\
\hline
\end{tabular}

Keteladanan dalam hal ini adalah keteladanan seorang guru sebagai publik figur atau sebagi contoh tauladan.Maka dalam tabel di atas, adalah bentuk kegiatan atau pelaksanaannya bagaimana guru ikutserta dan menjadi 
garda terdepan dalam melaksanakan pendidikan karakter di Sekolah/Madrasah (Agus Wibowo, 2012: 90).

4) Pengkondisian

Kalau kita berbicara dengan kondisi maka kita akan berfikir tentang keadaan sesuatu, maka terkait dalam pengkondisian dalam Pendidikan karakter adalah menyesuaikan keadaan. Sebagaimana yang di ungkapkan Agus Wibowo dalam bukunya Pendidikan Karakter ia mengatakan: (Agus Wibowo, 2012: 90-91).

"Untuk mendukung keterlaksanaan pendidikan karakter maka sekolah harus dikondisikan sebagai pendudukung kegiatan itu.Sekolah harus mencerminkan kehidupan nilai-nilai budaya dan karakter bangsa yang diinginkan. Misalnya, kondisi meja guru dan kepala sekolah yang rapi, toilet yang selalu bersih, bak sampah ada diberbagai tempat, dan selalu dibersihkan, sekolah terlihat rapi, dan alat belajar ditempatkan teratur."

Dari penjelasan Agus di atas maka pengkondisian adalah menyesuaikan lingkungan sekolah, peralatan sekolah, toilet, dan juga tempat pembuangan sampah yang semuanya itu harus sesuai dengan nilai karakter yang di tetapkan yakni cinta bersih dan peduli lingkungan.

\section{b. Implementasi Kendidikan Karakter Yang Diintegrasikan Mada Mata Pelajaran/bidang studi}

Pada setiap mata pelajaran di Sekolah Dasar/Madrasah sebenarnya telah memuat materi-materi yang mempunyai nilai-nilai karakter.Secara subtantif, setidak ada dua mata pelajaran yakni pendidikan Agama Islam dan dan Pendidikan Kewarganegaraan (PKn).Kedua mata pelajaran tersebut merupakan mata pelajaran yang secara langsug (eksplisit) mengenalkan nilai-nilai, dan sampai taraf tertentu menjadikan peserta didik peduli dan menginternalisasikan nilai-nilai. Integrasi pendidikan karakter pada mata pelajaran mengarah pada internalisasi nilai-nilai didalam tingkah laku sehari-hari melalui proses pembelajaran dari tahapan perencanaan, pelaksanaan dan penilaian (Kemendiknas, 2011: 21).

Pendidikan karakter juga diintegrasikan pada mata pelajaran, pengembangan nilai-nilai pendidikan karakter bangsa dintegrasikan dalam setiap pokok bahasan dari setiap mata pelajaran.Nilai-nilai tersebut di cantumkan dalam Silabus dan RPP.

"Terkait dengan pengembangan nilai-nilai tersebut maka detempuh dengan beberapa cara:

a. Mengkaji Standar Kompetensi (SK) dan Kompetensi Dasar (KD) pada Standar Isi (SI) untuk menentukan apakah nilai-nilai karakter bangsa yang akan di cantumkan. 
b. Menggunakan table 1 yang memperlihatkan keterkaitan antara SK dan KD dengan nilai dan indikatoruntuk menentukan nilai yang akan di kembangkan.

c. Mencantumkan nilai-nilai budaya dan karakter bangsa dalam table 1 kedalam silabus.

d. Mencantumkan nilai-nilai yang sudah tertera dalam silabus ke RPP.

e. Mengembangkan proses pembelajaran peserta didik secara aktif yang memungkinkan peserta didik memiliki kesempatan melakukan internalisasi nilai dan menunjukkannya dalam prilaku yang sesuai.

f. Memberikan bantuan kepada peserta didik, baik yang mengalami kesulitan untuk menginternalisasi nilai atau menunjukkannya dalam perilaku"(Sri Judiani, 2010: 285-286).

Dari penjelasan di atas dapat di pahami bahwa pendidikan karakter yang terintegrasi dalam mata pelajaran atau bidang studi melalui proses yang rumit, mulai dari mengkaji SK dan KD kemudian menentukan nilai-nilai yang di kembangakan dalam mata pelajaran tersebut, setelah itu mencantumkannya dalam RPP yang menjadi panduan guru dalam proses pembelajaran.

\section{c. Implementasi Kendidikan Karakter Yang Diintegrasikan Pada Kegiatan Ekstra Kurikuler}

Kegiatan ekstra kurikuler adalah kegiatan pendidikan diluar mata pelajaran dan pelayanan konseling untuk membantu pengembangan peserta didik sesuai dengan kebutuhan, potensi, dan minat mereka melalui kegiatan yang secara khusus diselenggarakan oleh pendidik dan tenaga pendidikan yang berkemampuan dan berkewenangan di sekolah(Jamal Ma'mur Asmani, 2011: 62-63).

Visi kegiatan ekstrakurikuler adalah berusaha untu mengembangkan potensi, bakat dan minat secara optimal, serta tumbuhnya kemandirian dan kebahagiaan peserta didik yang berguna untuk diri sendiri, keluarga dan masyarakat.Namun terkait dengan misi kegiatan ekstrakurikuler adalah, 1).Menyediakan sejumlah kegiatan yang dapat dipilih oleh peserta didik sesuai dengan kebutuhan, potensi, bakat, dan minat mereka; 2). Menyelenggarakan kegiatan yang memberikan kesempatan bagi peserta didik untuk mengaktualisasikan atau merealisasikan potensi, bakatnya secara bebas melaui kegiatan mandiri atau kelompok(Jamal Ma'mur Asmani, 2011: 63).

Kegiatan ekstra kurikuler mempunyai fungsi yang strategis dalam menyiapkan peserta didik untuk menjalani hidup kedepannya, adapun fungsi kegiatan ekstra adalah sebagai berikut:

a. Pengembangan, yaitu fungsi kegiatan ekstra kurikuler untuk mengembangkan kemampuan dan kreatifitas peserta didik sesuai dengan potensi, bakat dan minat mereka

b. Sosial, yaitu fungsi kegiatan ekstra kurikuler untuk mengembangkan kemampuan dan rasa tanggung jawab sosial peserta didik 
c. Rekreatif, yaitu fungsi kegiatan ekstra kurikuler untuk mengembangkan suasana rileks, mengembirakan dan menyenangkan bagi peserta didik yang menunjang proses perkembangan

d. Persiapan karir, yaitu fungsi kegiatan ekstra kurikuler untuk mengembangkan kesiapan karir peserta didik( D. Yahya Khan, 2010: 55).

Banyak sekali institusi pendidikan menganggap bahwa kegiatan ekstra kurikuler adalah kegiatan pelengkap intrakurikuler, dengan demikian kegiatan ekstra tak obahnya kegiatan penghibur, sehingga sering kali dipandang sebelah mata dan acuh tak acuh dengan kegiatan tersebut. Padahal jika didesain dengan bagus dengan manajeman yang professional maka kegiatan ekstra akan menjadi wahana atau wadah dalam melahirkan bakat terbesar dalam diri anak. Buakan hanya bakat akan tetapi nilai-nilai karakter yang mulai terkikis akan dapat ditanamkan kedalam diri peserta didik.

\section{Penutup}

Karakter merupakan nilai-nilai yang sangat urgen untuk dihabituasikan dalam pendidikan formal terutama dalam pendidikan dasar/ Madrasah ibtidaiyah, karena penanaman karakter sejak dini akan menjadikan anak mempunyai nilai-nilai yang baik yang tertanam dalam diri mereka, sehingga nilai-nilai itulah nantinya yang mereka bawa untuk bersosialisai baik dijenjang keluarga, lingkungan sekolah dan juga masyarakat. Kemudian yang yang terpenting lagi adalah kontrol dari orang tua untuk selalu membantu agar nilai-nilai yang ditanamkan disekolah juga ditanamkan dalam kehidupan keluarga dan juga orang tua menjadi suri tauladan atau garda terdepan untuk menciptakan nilai-nilai positif dalam keluarga itu, sehingga tidak ada anak tidak melihat sesuatu yang bertentangan apa yan ditanamkan disekolah tidak berbeda dengan apa yang orang tua lakukan.

\section{Daftar Pustaka}

Abdul Mujib \& Dian Andayani. 2011. Pendidikan Karakter Persepektif Islam.Bandung: Remaja Rosdakarya.

Ainullah, Nurla Isna. 2011. Panduan Menerapkan Pendidikan Karakter di Sekolah.Yogyakarta: DIVA Press.

al-Jazairi, Abu Bakar Jabir. 2000. Minhajul Muslim, Terjamahan, Ensiklopedi Muslim. Jakarta: Darul Falah.

Asmani, Jamal Ma'mur. 2011. Buku Panduan Internalisasi Pendidikan KArakter di Sekolah.Yogyakarta: DIVA Press.

Departemen Agama RI. 1983. Al-Qur'an dan Terjemahannya. Jakarta: Yayasan Penyelenggara Penterjemahan.

Departemen Agama RI, Ensiklopedi Islam di Indonesia, Jakarta: Anda Utama,

Hidayatullah, Furqon, Pendidikan Karakter Membangun Peradaban Bangsa Surakarta: Yuma

Husaini, Adian. 2010. Pendidikan; Membentuk Manusia Berkarakter dan Beradab.Kumpulan Makalah yang disajikan dalam Seminar Nasional 
Pendidikan Karakter Membangun Bangsa Beradab, Universitas Pendidikan Indonesia. Bandung. 28 Juli 2010.

Husein, Achmad dkk. 2010. Model pendidikan Karakter Bangsa. Jakarta: UNJ.

Judiani, Sri.2010.Implementasi Pendidikan Karakter di Sekolah Dasar Melalui Penguatan Pelaksanaan Kurikulum. Kemendiknas: Jurnal Pendidikan dan Kebudayaan, Vol. 16. Edisi Khusu III. Oktober 2010.

Kan, D. Yahya. 2010. Pendidikan Karakter Berbasis Potensi Diri; Mendongkrak Kualitas Pendidikan. Yogyakarta: Pelangai Publising.

Kemendiknas. 2011. Panduan Pelaksanaan Pendidikan Karakter.Jakarta: Kemendiknas Badan Peneilitian dan Pengembangan Puskurbuk.

2011. Pedoman Pelaksanaan Pendidikan Karakter (Berdasarkan Pengalaman di Satuan Pendidikan Rintisan).Jakarta: Badan Penelitian dan Pengembangan Pusat Kurikulum dan Perbukuan.

Kesuma, Darma dkk. 2011. Pendidikan Karakter, Kajian Teori dan Praktik di Sekolah.Bandung: Rosdakarya.

Masyhur, Kahar. 2001. Membina Moral dan Akhlak.Jakarta: Rineka Cipta.

Moeliono ,Anton M. 1996. Kamus Besar Bahasa Indonesia.Jakarta: Balai Pustaka.

Muchlas Samani \& Hariyanto. 2012. Konsep dan Model Pendidikan Karakter.Bandung: Remaja Rosdakarya.

Munawwir, Ahmad Warson. 2002. al-Munawwir, Kamus Arab Indonesia.Surabaya: Pustaka Progressif.

Mursidin. 2011. Moral Sumber Pendidikan; Sebuah Formula Pendidikan Budi Pekerti di Sekolah dan Madrasah. Bogor: Ghelia Indonesia.

Muslich, Masnur. 2011. Pendidikan Karakter Menjawab Tantangan Krisis Multidimensional.Jakarta: Bumi Aksara.

Pius A Partanto, Dahlan al-Barry. 2001. Kamus Ilmiah Populer.Surabaya: Arkola.

Siraj, Said Aqil. 2007. Tasawuf Sebagai Rekontruksi Sosial.Jakarta: Pustaka al-Kautsar.

Sofyan Sauri. 2010. Strategi Implementasi Pendidikan Karakter di Perguruan

Tinggi.Kumpulan makalah Seminar Internasional dan Workshop Pendidikan

karakter Menuju Terbentuknya Masyarakat yang Berbudi Pekerti Luhur, Bandung: Universitas Pendidikan Indonesia.

Suparno, dkk. 2002. Pendidikan Budi Pekerti di Sekolah. Yogyakarta: Kanisius.

Syah, Muhibbin. 2009. Psikologi Belajar.Jakarta: Rajawali Pers.

Walid, Muhammad. 2011. Model Pendidikan Karakter di Perguruan Tinggi Islam: Studi Tentang Pendidikan Karakter Berbasis Ulul albab di Universitas Islam Maulana Malik Ibrahim Malang. Malang: Jurnal el-Qudwah vol 1 No 5 Edisi April.

Wibowo, Agus. 2012, Pendidikan Karakter, Strategi Membangun Karakter Bangsa Berperadaban. Yogyakarta: Pustaka Pelajar. 